\title{
Kecemasan Matematika Siswa Sekolah Menengah pada Pembelajaran Matematika dalam Jaringan
}

\author{
Inggita Nurjanah ${ }^{1}$, Fitri Alyani ${ }^{2 *}$ \\ ${ }^{1,2}$ Program Studi Pendidikan Matematika, Fakultas Keguruan dan Ilmu Pendidikan, Universitas \\ Muhammadiyah Prof. Dr. Hamka \\ *fitrialyani@uhamka.ac.id
}

\begin{abstract}
Abstrak
Kecemasan matematika siswa sekolah tingkat menengah pada pembelajaran matematika banyak berpengaruh dalam berlangsungnya pembelajaran. Pengaruh kecemasan matematika tersebut berpengaruh mulai dari pemahaman konsep matematika sampai pada hasil belajar siswa. Penelitian ini bertujuan untuk mengetahui tingkatan kecemasan yang dialami oleh siswa dalam menjalani pembelajaran dalam jaringan dan mengetahui bias yang terjadi anatara responden dengan pernyataan pada kuisioner. Penelitian ini dilakukan melalui pendekatan gabungan antara kuantitatif dan kualitatif dengan menggunakan metode survey. Subjek penelitian ini adalah siswa dengan rentang pendidikan tingkat menengah yang sedang menjalani pembelajaran matematika dalam jaringan yang dipilih melalui teknik Random Sampling dan berjumlah 225 siswa dengan siswa perempuan sebanyak 155 siswa dan siswa laki-laki sebanyak 70 siswa. Pengumpulan data dilakukan melalui penyebaran instrumen berbentuk kuisioner mengenai kecemasan matematika siswa. Selanjutnya data yang didapatkan diukur melalui model rasch dan diolah dengan bantuan aplikasi Winsteps. Setelah data didapatkan maka dilakukan wawancara kepada 3 siswa dipilih berdasarkan nilai logit yang mewakili setiap tingkat kecemasan matematika untuk mendapatkan informasi secara spesifik sekaligus sebagai upaya elaborasi dalam penelitian ini untuk mengetahui penyebab yang mendukung terjadi kecemasan matematika siswa pada sistem pembelajaran dalam jaringan. Dalam penelitian ini diperolah hasil bahwa, dalam pelaksanaan pembelajaran dalam jaringan kecemasan matematika cenderung masih tinggi dan terdapat tiga kategori, diantaranya kecemasan tinggi 17,33\%, kecemasan sedang 73,78 \%, dan kecemasan rendah 8,89\%. Dalam penelitian ini juga didapatkan berbagai pemicu hadirnya kecemasan matematika yang dapat dijadikan referensi dalam memahami kondisi siswa. Melalui DIF (Differential Item Functioning) didapatkan bahwa terdapat perbedaan/bias yang dapat dijadikan referensi penelitian selanjutnya.
\end{abstract}

Kata Kunci: kecemasan, matematika, pembelajaran dalam jaringan

\begin{abstract}
Mathematics anxiety of high school students in learning mathematics in the network has a lot of influence on the ongoing learning until the results obtained. The influence of math anxiety has an effect ranging from understanding mathematical concepts to student learning outcomes. This study aims to determine the level of anxiety experienced by students in undergoing online learning and determine the bias between respondents and statements on the questionnaire. This research was conducted through a combined approach of quantitative and qualitative using a survey method. The subjects of this research are students with a range of secondary education who are undergoing online learning and totaling 225 students with 155 female students and 70 male students. Data was collected through the distribution of an instrument in a questionnaire regarding students' mathematics anxiety. Furthermore, the data obtained is measured through the Rasch model and processed with the help of the Winsteps application. After the data was obtained, interviews were conducted to determine the causes that support students' mathematical anxiety in the online learning system. In this study, the results obtained
\end{abstract}


that anxiety tends to be high in the implementation of learning in the network. There are three categories: high anxiety $17.33 \%$, moderate anxiety $73.78 \%$, and low anxiety $8.89 \%$. This study also found various triggers for the presence of mathematical anxiety that can be used to understand the condition of students. Through DIF (Differential Item Functioning), some differences/biases can be used as references for further research.

Keywords: anxiety, mathematics, online learning

Received: May 25, 2021 / Accepted: June 28, 2021 / Published Online: July 15, 2021

\section{Pendahuluan}

Salah satu cabang ilmu pengetahuan yang dipelajari di sekolah ialah matematika (Puspaningtyas, 2019). Sehingga pembelajaran matematika merupakan pembelajaran yang perlu dipahami dan dikuasai oleh segenap lapisan masyarakat, terutama dalam berbagai jenjang pendidikan (Kusumawardani et al., 2018). Bahkan pembelajaran matematika dapat dijadikan salah satu cara untuk mewujudkan peradaban suatu bangsa (Janah et al., 2019). Selain itu, saat ini kemampuan matematika juga sangat penting dimiliki oleh setiap manusia karena matematika tidak hanya berpengaruh pada bidang sains, teknologi, teknik, dan matematika (STEM) bidang terkait, tetapi matematika juga berpengaruh pada kehidupan sehari-hari dengan kualitas teknologi tinggi seperti saat ini (Namkung et al., 2019). Hal tersebut juga diperkuat oleh laporan pada National Research Council dalam (Siregar \& Restati, 2017) bahwa kedudukan matematika saat ini bukan hanya sekedar simbol, tetapi juga berkontribusi secara langsung dan fundamental pada bisnis, kesehatan, keuangan, dan pertahanan.

Meskipun demikian, tidak banyak siswa yang menyukai pelajaran matematika dan matematika seringkali dianggap sebagai mata pelajaran yang sulit (Disai et al., 2017; Utami et al., 2020). Objek yang abstrak dan banyak berkaitan dengan rumus membuat matematika terkesan sulit dan rumit (Juliyanti \& Pujiastuti, 2020). Selain karena dianggap sulit, terdapat faktor lain yang juga berpengaruh saat memahami matematika. Salah satu faktor tersebut ialah kecemasan matematika (Santri, 2017). Jolejole-Caube et al. (2019), mengatakan bahwa kecemasan matematika adalah suatu kondisi dimana siswa merespon suatu tugas matematika dengan perasaan tegang atau takut. Selain itu, kecemasan matematika juga didefinisikan sebagai perasaan cemas, tegang, atau takut yang mengganggu kemampuan kerja matematika serta lebih memilih menghindari situasi saat harus memahami dan mengerjakan matematika (Santri, 2017). Kecemasan matematika juga dapat diartikan sebagai dampak negatif yang berasal dari respon emosional, berupa perasaan khawatir, tegang, takut, dan was-was ketika berhadapan dengan pembelajaran matematika (Juliyanti \& Pujiastuti, 2020). Maka dapat 
diartikan bahwa kecemasan matematika ialah suatu perasaan cemas, tegang, dan takut saat harus mengikuti pembelajaran ataupun menyelesaikan permasalahan mengenai matematika.

Santri (2017) mengatakan bahwa kecemasan matematika berkembang pada anak-anak dan remaja sekaligus menjadi suatu hambatan yang sangat serius. Kecemasan matematika memiliki berbagai pengaruh dalam berjalannya suatu pembelajaran matematika. Kecemasan matematika dapat menimbulkan rendahnya pemahaman, kurang kemampuan dalam menghitung, dan rendahnya upaya dalam menumbuhkan strategi dan hubungan antar domain matematika (Zakariya, 2018). Kecemasan matematika juga dipengaruhi oleh gender. Siswa perempuan cenderung memiliki kecemasan matematika lebih tinggi dari siswa laki-laki dan semakin tinggi kecemasan matematika yang dimiliki oleh seorang siswa, maka semakin rendah prestasi yang dimiliki oleh siswa tersebut (Kusumawati \& Nayazik, 2017; Recber et al., 2018). Selain itu kecemasan matematika juga berpengaruh terhadap performa matematika siswa. Kecemasan matematika dan performa matematika memiliki hubungan negatif, dimana saat kecemasan matematika siswa tinggi maka performa matematika siswa akan rendah begitupun sebaliknya (Namkung et al., 2019). Performa tersebut juga dipengaruhi oleh konten matematika dan gaya mengajar seorang guru. Konten matematika dan gaya mengajar yang baik dan sesuai dapat menekan persentase kecemasan yang dirasakan siswa (Kusmaryono et al., 2020). Kecemasan matematika dipengaruhi oleh sikap siswa itu sendiri. Dalam penelitian Ardi et al. (2019), menghasilkan bahwa self-efficacy dan value belief yang dimiliki oleh siswa dapat menurunkan kecemasan matematika siswa, dengan begitu prestasi yang dimiliki siswa pun dapat ditingkatkan pula.

Kondisi pembelajaran saat ini juga berpengaruh terhadap kecemasan matematika siswa. Lebih dari 800 juta siswa di Indonesia pada bulan Maret 2020 harus melaksanakan pembelajaran dalam jaringan (Oktawirawan, 2020). Pembelajaran dalam jaringan ialah pembelajaran yang menggunakan jaringan internet dan beberapa perangkat lalu dilaksanakan secara jarak jauh (Putria et al., 2020). Pembelajaran dengan sistem dalam jaringan dapat memudahkan siswa untuk mengakses pembelajaran dimanapun dan kapanpun (Shukla et al., 2020). Pembelajaran secara dalam jaringan pun dapat memudahkan siswa untuk mendapatkan informasi yang lebih luas dan mendalam melalui internet (Hastini et al., 2020). Pembelajaran dalam jaringan juga menyediakan fleksibilitas mengenai waktu dan tempat dalam pelaksanaannya (Putria et al., 2020). Meskipun demikian pembelajaran dalam jaringan tak selamanya menemukan kemudahan dan kelebihan dalam penerapannya. 
Beberapa kendala hadir sebagai pemicu kecemasan saat menjalani pembelajaran dalam jaringan. Kendala-kendala selama pembelajaran akan memunculkan sebuah kekhawatiran yang berakhir pada sebuah kecemasan (Apsari et al., 2020). Kecemasan matematika cenderung tinggi dalam pembelajaran dalam jaringan yang dipicu oleh kondisi lingkungan yang tidak mendukung dan perasaan bosan karena terlalu sering berinteraksi dengan gawai (Nabilah et al., 2021). Penggunaan internet seringkali menjadi kendala besar bagi beberapa daerah yang belum terjamah oleh jaringan internet (Oktawirawan, 2020). Selain karena jaringan, tak sedikit keluarga yang merasa terbebani dengan alokasi pendanaan untuk kuota internet setiap bulannya (Morgan, 2020). Masalah lain yang masih selaras ialah kurangnya ketersediaan perangkat penunjang pembelajaran yang disebabkan oleh internet ataupun penggunaan aplikasi yang terlampau besar (Mulyana et al., 2021; Purwanto et al., 2020). Kapasitas tugas yang bertambah pun memicu siswa mengalami kecemasan matematika (Catherine, 2020).

Salah satu jenjang pendidikan yang merasakan kecemasan tersebut ialah jenjang pendidikan menengah. Kecemasan yang dirasakan siswa tingkat menengah berpengaruh dalam berjalanan pembelajaran. Saat pembelajaran matematika, kecemasan dapat mempengaruhi siswa tingkat menengah dalam melakukan pemahaman terhadap konsep matematika (Handayani, 2019). Kecemasan matematika juga berpengaruh pada kemampuan pemecahan masalah yang dimiliki oleh siswa tingkat menengah (Rizki et al., 2019). Selain itu, kecemasan matematika yang dialami siswa tingkat menengah juga berpengaruh pada kemampuan penalaran adaptif yang dimiliki siswa (Wijaya et al., 2019). Bahkan pada hasil belajar pun, kecemasan memiliki pengaruh terhadap hasil belajar yang dimiliki siswa tingkat menengah (Ikhsan, 2019). Dengan berbagai keadaan tersebut, penelitian ini bertujuan untuk menggambarkan kondisi tingkatan kecemasan siswa dalam menjalani pembelajaran dalam jaringan berdasarkan indikator kecemasan matematika menurut Mulyana et al. (2021) dan respon siswa dalam pembelajaran yang dapat memicu hadirnya kecemasan yang dialami oleh siswa sekolah tingkat menengah yang dapat dijadikan referensi khususnya bagi tenaga pengejar dalam memahami kondisi siswa sebelum menyiapkan pembelajaran dalam jaringan.

\section{Metode}

Desain penelitian yang dilakukan menggunakan penelitian gabungan eksploratori (exploratory mixed-method research design) untuk menjelaskan kecemasan matematika yang terjadi pada siswa tingkat menengah saat menjalani pembelajaran dalam jaringan dengan pendekatan kuantitatif dalam validasi dan analisis instrumen kuisioner yang dilanjutkan dengan 
analisis kualitatif deskriptif. Metode penelitian gabungan ini dilakukan dengan melibatkan subjek penelitian sebanyak 225 siswa dengan siswa perempuan sebanyak 155 siswa dan siswa laki-laki sebanyak 70 siswa yang berada pada sekolah tingkat menengah pertama sampai sekolah tingkat menengah atas. Subjek penelitian mengisi kuisioner yang terbagi atas 5 kategori demografis (disajikan pada tabel 1) dan 20 item pernyataan untuk mendeteksi tingkat kecemasan matematika yang terjadi pada siswa tingkat menengah dalam menjalani pembelajaran dalam jaringan. Selanjutnya dilakukan wawancara kepada siswa yang mewakili ketiga tingkatan kecemasan matematika berdasarkan nilai logit yang didapatkan dan mewakili setiap kategori kecemasan. Wawancara ini dilakukan untuk mendapatkan informasi secara spesifik sekaligus sebagai upaya elaborasi dalam penelitian ini.

Instrumen yang digunakan diadopsi dari artikel berjudul development of anxiety mathematics skill (Zakariya, 2018). Pernyataan sebanyak 20 item diterjemahkan supaya siswa lebih mudah memahami setiap pernyataan yang tersedia dan disebarkan dalam bentuk google form untuk mempermudah tabulasi dan pengumpulan data (Ningsih et al., 2018). Langkah perhitungan dilakukan dengan menggunakan Model Rasch melalui bantuan aplikasi Winsteps versi 4.4.2. Aplikasi Winsteps dapat melakukan perhitungan skor mentah dari excel menjadi data logit/log unit ganjil. Dalam mengolah data tersebut, Winsteps dapat menyajikan kualitas butir instrumen, dan kualitas responden, kualitas keduanya bahkan pengelompokan siswa ke dalam tiga tingkatan kecemasan (Sudihartinih \& Wahyudin, 2019; Willse, 2017).

Tabel 1. Keterangan Demografis

\begin{tabular}{ccc}
\hline Demografi & Keterangan & Label \\
\hline \multirow{5}{*}{ Kelas Setiap Jenjang } & Kelas 1 SMA & $\mathrm{A}$ \\
\cline { 2 - 3 } & Kelas 2 SMA & $\mathrm{B}$ \\
\cline { 2 - 3 } & Kelas 3 SMA & $\mathrm{C}$ \\
\cline { 2 - 3 } & Kelas 1 SMP & $\mathrm{D}$ \\
\cline { 2 - 3 } & Kelas 2 SMP & $\mathrm{E}$ \\
\cline { 2 - 3 } Domisili & Kelas 3 SMP & $\mathrm{F}$ \\
\cline { 2 - 3 } & Jabodetabek & $\mathrm{Q}$ \\
\cline { 2 - 3 } & Jawa Tengah \& Timur & $\mathrm{R}$ \\
\cline { 2 - 3 } Gender & Sumatera & $\mathrm{S}$ \\
\cline { 2 - 3 } & Sulawesi & $\mathrm{T}$ \\
\cline { 2 - 3 } & Kalimantan & $\mathrm{U}$ \\
\hline \multirow{3}{*}{ Jenjang Pendidikan } & Perempuan & $\mathrm{G}$ \\
\cline { 2 - 3 } & Laki-Laki & $\mathrm{H}$ \\
\cline { 2 - 3 } & SMP & $\mathrm{I}$ \\
\hline \multirow{3}{*}{ Jurusan Pendidikan } & SMA & $\mathrm{J}$ \\
\cline { 2 - 3 } & SMK & $\mathrm{K}$ \\
\cline { 2 - 3 } & IPA & $\mathrm{M}$ \\
\cline { 2 - 3 } & IPS & $\mathrm{O}$ \\
\cline { 2 - 3 } & Lahasa & Kejuruan \\
\hline
\end{tabular}


Langkah perhitungan selanjutnya adalah melalui DIF. DIF adalah perbedaan probabilitas yang dilakukan setelah mengontrol tingkat kemampuan responden dalam menjawab suatu item butir soal berdasarkan beberapa kelompok yang ada (Jend et al., 2012). Hal ini penting juga dilakukan dalam sebuah penelitian karena dengan mendeteksi DIF yang ada, maka akan semakin mengetahui tingkat keadilan yang terjadi pada suatu instrumen (Setiawan et al., 2016). Selanjutnya hasil dari perhitungan penelitian ditindaklanjuti melalui wawancara semiterstruktur. Pada bagian ini dipilih 3 siswa dari 225 siswa dari setiap tingkat kecemasan yang ada. Ketiga siswa tersebut dipilih berdasarkan dari nilai logit yang mewakili setiap tingkat kecemasan matematika (rendah, sedang dan tinggi). Wawancara dilakukan dengan santai dan menggunakan bahasa Indonesia untuk mengekspresikan apa yang sepenuhnya mereka rasakan selama pembelajaran dan dilakukan secara mendalam dan terperinci. Wawancara yang dilakukan selama 8-15 menit ini direkam dengan audio untuk mempermudah saat menuangkan hasil wawancara menjadi sebuah transkip penelitian.

\section{Hasil Penelitian}

\section{Hasil dari penelitian studi kuantitatif}

Hasil perhitungan studi kuantitatif didapatkan melalui bantuan aplikasi Winsteps. Penelitian kuantitatif melalui Winsteps dapat memberikan data secara menyeluruh mengenai kualitas item, kualitas person, bahkan hubungan yang terjadi antara item dan person. Data mengenai kualitas item, person, dan hubungan keduanya diwakili dalam tabel summary statistics pada tabel 2. Kualitas kemampuan responden (person measure) dilihat melalui ratarata nilai siswa sebesar 0,07logit berarti bahwa kesulitan siswa dalam merespon item lebih tinggi dibandingkan dengan kualitas dari item itu sendiri. Dengan kata lain kemampuan yang dimiliki siswa cenderung lebih rendah dibandingkan dengan tingkat kesulitan item (Sumintono \& Widhiarso, 2015). Sedangkan kualitas kesukaran butir soal (item measure) dapat dilihat melalui kombinasi antara standar deviasi dengan rata-rata logit (Sumintono \& Widyiarso, 2015). Dengan standar deviasi 0,78 dan logit rata-rata measure 0,0 maka katagori soal yang diberikan kepada responden ialah sulit. Nilai person reliability dan item reliability berturutturut ialah 0,83 dan 0,98 . Hal tersebut menyatakan bahwa konsistensi siswa dalam menjawab item bagus dan kualitas item yang digunakan merupakan item-item istimewa/berkualitas. Adapun alpha cronbach bernilai 0,86 menyatakan bahwa hubungan interaksi antara person dengan item dalam instrumen ini adalah bagus sekali (Sumintono \& Widhiarso, 2014). 
Tabel 2. Summary Statistics

\begin{tabular}{cccccc}
\hline & Mean & SD & $\begin{array}{c}\text { Separation } \\
\text { Index }\end{array}$ & Reliability & Cronbach \\
\cline { 1 - 4 } Person & $-0,07$ & 0,86 & 2,17 & 0,83 & \multirow{2}{*}{0,86} \\
\hline Item & 0.00 & 0,78 & 7,67 & 0,98 & \\
\hline
\end{tabular}

Data lain yang didapatkan dari penelitian ialah mengenai kesesuaian butir soal (item fit) dan kesesuaian responden dalam menjawab pernyataan (person fit). Pada tabel 3 dapat melihat bahwa secara general pernyataan yang digunakan dalam kuisioner dapat digunakan (item fit), karena mean-square dan z-standard memenuhi kriteria meskipun point measure correlation terlampau sangat tinggi. Begitupun dengan person fit, secara general person fit dapat digunakan karena mean-square dan z-standard memenuhi kriteria meskipun point measure correlation terlampau sangat rendah.

Tabel 3. Kualitas Kesesuaian Person dan Item

\begin{tabular}{cccc}
\hline & MNSQ & ZSTD & Correlation \\
\hline Person & 1,01 & $-0,25$ & 0,97 \\
\hline Item & 1,01 & $-0,30$ & $-1,00$ \\
\hline
\end{tabular}

Selanjutnya hasil penelitian mengenai tingkatan kecemasan matematika yang dirasakan siswa tingkat menengah disajikan melalui person map. Urutan kecemasan tersebut dapat disajikan pada gambar 1 .

Selain urutan kecemasan yang dirasakan siswa dalam pembelajaran dalam jaringan, didapatkan hasil penelitian mengenai persentase kecemasan matematika pada setiap kategorinya. Persentase tersebut disajikan melalui tabel 4 dan dapat terlihat bahwa masingmasing kecemasan rendah, kecemasan sedang, dan kecemasan tinggi masing-masing memiliki persentase sebesar 8,89\% untuk kecemasan rendah, 73,78\% untuk kecemasan sedang, dan $17,33 \%$ persentase untuk kategori kecemasan tinggi.

Tabel 4. Kategori Kecemasan Matematika

\begin{tabular}{ccc}
\hline Kategori Kecemasan & Frekuensi & Persentase \\
\hline Rendah & 20 Responden & $8,89 \%$ \\
\hline Sedang & 166 Responden & $73,78 \%$ \\
\hline Tinggi & 39 Responden & $17,33 \%$ \\
\hline
\end{tabular}

Hasil dari penelitian studi kuantitatif selanjutnya menyajikan data mengenai nilai probabilitas dari masing-masing demografi terhadap setiap item pernyataan yang terdapat pada kuisioner. Data disajikan pada tabel 5. Demografi dengan nilai probablitas dibawah 0,05 merupakan demografi yang mengalami bias. Melalui tabel probabilitas berikut dapat diketahui mana saja item pernyataan yang masih mengalami bias dan dalam perhitungan Winsteps juga dapat dikatakan sebagai item yang mengalami DIF. Dapat dilihat bahwa terjadi DIF terjadi pada item no. 1 (saya merasa lebih gugup selama mengikuti pembelajaran matematika secara daring) seluruh demografi mengalami DIF kecuali pada bagian gender. Selanjutnya, DIF terjadi 
pada item no. 10 (wajar bagi saya mengalami kesulitan selama pembelajaran matematika secara daring) hanya terjadi pada pengelompokan gender. Terakhir DIF juga terjadi pada item no.16 (saya tahu bahwa selama pembelajaran saya mampu mengerjakan matematika dengan baik) terjadi pada bagian domisili, jenjang pendidikan, dan jurusan sekolah.

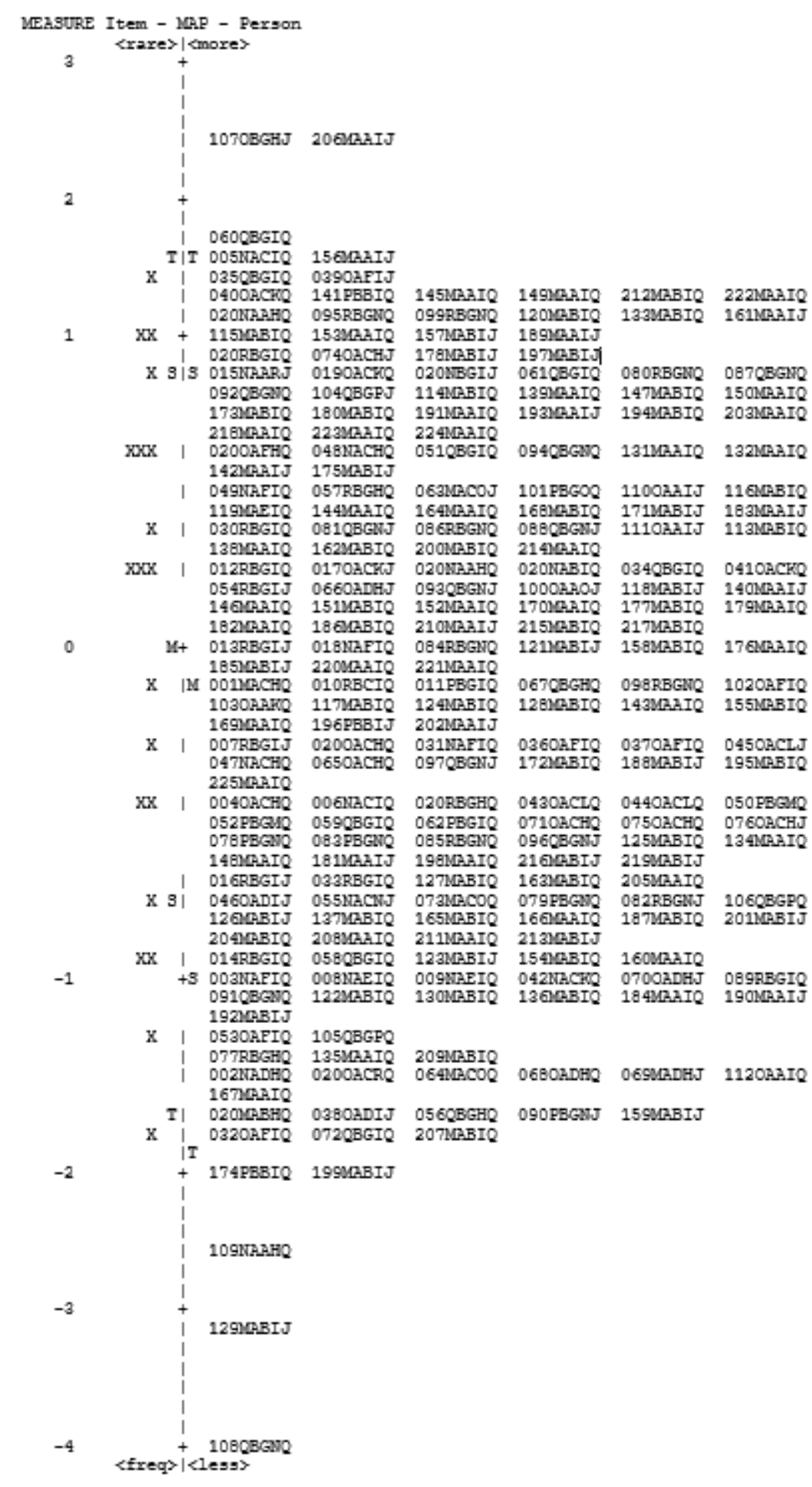

Gambar 1. Person Map Kecemasan Matematika 
Tabel 5. Nilai Probabilitas setiap demografi terhadap masing-masing item

\begin{tabular}{cccccc}
\hline Item & Kelas & Domisili & Gender & Jenjang & Jurusan \\
\hline 1 & 0,0000 & 0,0110 & 0,2537 & 0,0029 & 0,0018 \\
\hline 2 & 0,4418 & 0,2278 & 0,7920 & 0,1208 & 0,1255 \\
\hline 3 & 0,3081 & 0,0990 & 0,6580 & 0,1747 & 0,1270 \\
\hline 4 & 0,5914 & 0,6733 & 0,2381 & 0,1770 & 0,3838 \\
\hline 5 & 0,5059 & 0,7165 & 0,6843 & 0,3131 & 0,5745 \\
\hline 6 & 0,9065 & 0,7032 & 0,8014 & 0,3891 & 0,4472 \\
\hline 7 & 0,2632 & 0,3807 & 0,4144 & 0,8528 & 0,9132 \\
\hline 8 & 0,8102 & 0,2606 & 0,0748 & 0,6758 & 0,6338 \\
\hline 9 & 0,5184 & 0,9538 & 0,4060 & 0,2953 & 0,6394 \\
\hline 10 & 0,8881 & 0,3856 & 0,0032 & 0,4842 & 0,7924 \\
\hline 11 & 0,7452 & 0,8579 & 0,0979 & 0,7383 & 0,8706 \\
\hline 12 & 0,3168 & 0,9461 & 1,0000 & 0,1430 & 0,3981 \\
\hline 13 & 0,5715 & 0,8947 & 0,4102 & 0,3618 & 0,6225 \\
\hline 14 & 0,2560 & 0,9674 & 0,4109 & 0,5264 & 0,7206 \\
\hline 15 & 0,9595 & 0,3572 & 0,2413 & 0,7811 & 0,2291 \\
\hline 16 & 0,0511 & 0,0323 & 0,2597 & 0,0313 & 0,0174 \\
\hline 17 & 0,8632 & 0,9522 & 0,2620 & 0,9470 & 0,7921 \\
\hline 18 & 0,7483 & 0,3837 & 0,2464 & 0,4236 & 0,6672 \\
\hline 19 & 0,7024 & 0,6079 & 0,4370 & 0,5056 & 0,6112 \\
\hline 20 & 0,5909 & 0,1782 & 0,6070 & 0,5942 & 0,3530 \\
\hline
\end{tabular}

Berdasarkan tabel 5 maka selanjutnya data diperjelas dengan menampilkan tabel 6 mengenai nilai probabilitas pada setiap item pernyataan bias terhadap masing-masing demografi yang secara keseluruhan.

Tabel 6. Nilai Probabilitas antara demografi dengan item pernyataan bias

\begin{tabular}{|c|c|c|c|c|}
\hline & & 1 & 10 & 16 \\
\hline \multirow{6}{*}{$\begin{array}{c}\text { Jenjang } \\
\text { Setiap } \\
\text { Kelas }\end{array}$} & $\mathrm{A}$ & 0,5712 & 10,965 & 0,7361 \\
\hline & $\mathrm{B}$ & $-0,3173$ & 0,9786 & 0,3057 \\
\hline & $\mathrm{C}$ & $-0,5407$ & 0,999 & 0,2096 \\
\hline & D & $-0,3375$ & 0,7543 & 0,2975 \\
\hline & $\mathrm{E}$ & 17,109 & 0,9124 & 0,8214 \\
\hline & $\mathrm{F}$ & $-0,0056$ & 0,7248 & 0,6411 \\
\hline \multirow{2}{*}{ Gender } & $\mathrm{G}$ & 0,2992 & $-11,898$ & 0,4956 \\
\hline & $\mathrm{H}$ & 0,5414 & $-0,5412$ & 0,7376 \\
\hline \multirow{3}{*}{$\begin{array}{c}\text { Jenjang } \\
\text { Pendidikan }\end{array}$} & $\mathrm{I}$ & 0,5873 & 0,8057 & 0,6598 \\
\hline & $\mathrm{J}$ & 0,4381 & 10,798 & 0,6407 \\
\hline & $\mathrm{K}$ & $-0,8157$ & 0,9732 & $-0,3129$ \\
\hline \multirow{5}{*}{$\begin{array}{c}\text { Jurusan } \\
\text { Pendidikan }\end{array}$} & $\mathrm{L}$ & 14,181 & 14,172 & 14,189 \\
\hline & M & 0,6734 & 10,250 & 0,8721 \\
\hline & $\mathrm{N}$ & 0,126 & 11,465 & 0,3368 \\
\hline & $\mathrm{O}$ & 0,5873 & 0,8057 & 0,6598 \\
\hline & $\mathrm{P}$ & $-0,8157$ & 0,9732 & $-0,3129$ \\
\hline \multirow{5}{*}{ Domisili } & Q & 0,319 & 10,480 & 0,481 \\
\hline & $\mathrm{R}$ & 0,5503 & 13,055 & 0,7884 \\
\hline & $\mathrm{S}$ & $-0,9658$ & 0,574 & 0,172 \\
\hline & $\mathrm{T}$ & 13,286 & 0,5161 & 15,310 \\
\hline & $\mathrm{U}$ & $-19,874$ & 22,521 & $-13,036$ \\
\hline
\end{tabular}




\section{Hasil dari penelitian studi kualitatif}

Hasil studi berdasarkan penelitian kualitatif dilakukan sebagai upaya elaborasi data mengenai kecemasan yang dirasakan siswa sekolah tingkat menengah yang dilakukan melalui wawancara. Wawancara dilakukan dengan memberikan pertanyaan (Q) kepada 3 siswa berdasarkan nilai logit yang menyatakan kategori kecemasan rendah $\left(\mathrm{A}_{1}\right)$, kecemasan sedang $\left(A_{2}\right)$, dan kecemasan tinggi $\left(A_{3}\right)$ melalui tabel 7 berikut.

Tabel 7. Hasil cuplikan wawancara

\begin{tabular}{|c|c|c|c|c|c|}
\hline $\mathrm{Q}=$ & $\begin{array}{l}\text { Apakah kamu lebih suka } \\
\text { pembelajaran } \\
\text { matematika dalam } \\
\text { jaringan dibandingkan } \\
\text { dengan pembelajaran } \\
\text { matematika tatap muka? }\end{array}$ & $\mathrm{Q}=$ & $\begin{array}{l}\text { Apakah kamu lebih suka } \\
\text { pembelajaran } \\
\text { matematika dalam } \\
\text { jaringan dibandingkan } \\
\text { dengan pembelajaran } \\
\text { matematika tatap muka? }\end{array}$ & $\mathrm{Q}=$ & $\begin{array}{l}\text { Apakah kamu lebih suka } \\
\text { pembelajaran matematika } \\
\text { dalam jaringan } \\
\text { dibandingkan dengan } \\
\text { pembelajaran matematika } \\
\text { tatap muka? }\end{array}$ \\
\hline $\mathrm{A}_{1}=$ & $\begin{array}{l}\text { Saya merasakan plus- } \\
\text { minus nya dalam } \\
\text { pembelajaran dalam } \\
\text { jaringan ini bu. Saya } \\
\text { kewalahan dan kesal } \\
\text { dengan tugas yang } \\
\text { lebih banyak dan sulit } \\
\text { konsentrasi bu. } \\
\text { Meskipun saya juga } \\
\text { rasakan bahwa dengan } \\
\text { kondisi ini saya } \\
\text { menjadi tau referensi } \\
\text { lain selain buku yang } \\
\text { diberikan sekolah }\end{array}$ & $\mathrm{A}_{2}=$ & $\begin{array}{l}\text { Saya merasa kurang } \\
\text { nyaman saat harus } \\
\text { menjalani pembelajaran } \\
\text { dalam jaringan ini bu. } \\
\text { Pembelajaran dalam } \\
\text { jaringan lebih banyak } \\
\text { tugas dan saya kurang } \\
\text { faham materi. Belum } \\
\text { lagi terkait deadline } \\
\text { tugas yang terkadang } \\
\text { sangat singkat. } \\
\text { Terkadang juga saya } \\
\text { menghindari sengaja } \\
\text { menghindari meet bu. }\end{array}$ & $\mathrm{A}_{3}=$ & $\begin{array}{l}\text { Saya tidak suka dengan } \\
\text { pembelajaran dalam } \\
\text { jaringan ini bu. Saya lebih } \\
\text { suka bertemu teman tanpa } \\
\text { harus di rumah seperti saat } \\
\text { ini bu. Karena jujur, } \\
\text { kondisi rumah saya tidak } \\
\text { mendukung saya dalam } \\
\text { menjalani pembelajaran } \\
\text { dalam jaringan. Saya } \\
\text { merasa kesal karena tidak } \\
\text { faham, dan bingung harus } \\
\text { seperti apa bu. }\end{array}$ \\
\hline $\mathrm{Q}=$ & $\begin{array}{l}\text { Apakah kamu sering } \\
\text { merasakan cemas } \\
\text { karena mengalami } \\
\text { kesulitan dalam } \\
\text { menentukan proses } \\
\text { pembelajaran yang } \\
\text { akan kamu lakukan? }\end{array}$ & $\mathrm{Q}=$ & $\begin{array}{l}\text { Apakah kamu sering } \\
\text { merasakan cemas karena } \\
\text { mengalami kesulitan } \\
\text { dalam menentukan } \\
\text { proses pembelajaran } \\
\text { yang akan kamu } \\
\text { lakukan? }\end{array}$ & $\mathrm{Q}=$ & $\begin{array}{l}\text { Apakah kamu sering } \\
\text { merasakan cemas karena } \\
\text { mengalami kesulitan dalam } \\
\text { menentukan proses } \\
\text { pembelajaran yang akan } \\
\text { kamu lakukan? }\end{array}$ \\
\hline $\mathrm{A}_{1}=$ & $\begin{array}{l}\text { Dalam mempersiapkan } \\
\text { pembelajaran saya } \\
\text { merasa aman bu. Saya } \\
\text { juga memiliki fasilitas } \\
\text { wi-fi yang } \\
\text { memudahkan saya } \\
\text { dalam mengikuti } \\
\text { pembelajaran. }\end{array}$ & $\mathrm{A}_{2}=$ & $\begin{array}{l}\text { Lumayan bu, karena } \\
\text { saya termasuk yang } \\
\text { berkendala dengan } \\
\text { jaringan. Saya juga } \\
\text { sering merasa bingung } \\
\text { bagaimana harus } \\
\text { berperan aktif saat } \\
\text { pembelajaran karena } \\
\text { percaya diri yang } \\
\text { menurun. }\end{array}$ & $\mathrm{A}_{2}=$ & $\begin{array}{l}\text { Saya sangat merasa } \\
\text { kesulitan dalam } \\
\text { mempersiapkan } \\
\text { pembelajaran bu, karena } \\
\text { semua terasa berbeda dan } \\
\text { saya sudah tidak } \\
\text { memahami matematika } \\
\text { sejak awal. }\end{array}$ \\
\hline $\mathrm{Q}=$ & $\begin{array}{l}\text { Apakah kamu merasa } \\
\text { cemas karena bingung } \\
\text { dalam memahami } \\
\text { matematika saat } \\
\text { pembelajaran dalam } \\
\text { jaringan? }\end{array}$ & $\mathrm{Q}$ & $\begin{array}{l}\text { Apakah kamu merasa } \\
\text { cemas karena bingung } \\
\text { dalam memahami } \\
\text { matematika saat } \\
\text { pembelajaran dalam } \\
\text { jaringan? }\end{array}$ & $\mathrm{Q}=$ & $\begin{array}{l}\text { Apakah kamu merasa } \\
\text { cemas karena bingung } \\
\text { dalam memahami } \\
\text { matematika saat } \\
\text { pembelajaran dalam } \\
\text { jaringan? }\end{array}$ \\
\hline
\end{tabular}




\begin{tabular}{|c|c|c|c|c|c|}
\hline $\mathrm{A}_{1}=$ & $\begin{array}{l}\text { Tidak sampai } \\
\text { mengalami kecemasan } \\
\text { sih bu. Terkadang saya } \\
\text { mengalami kendala } \\
\text { tapi mempu } \\
\text { terselesaikan dengan } \\
\text { bantuan google, } \\
\text { youtube, teman, } \\
\text { ataupun kakak saya di } \\
\text { rumah. }\end{array}$ & $\mathrm{A}_{2}=$ & $\begin{array}{l}\text { Ya bu, selama } \\
\text { pembelajaran dalam } \\
\text { jaringan saya sering } \\
\text { bingung dalam } \\
\text { memahami materi dan } \\
\text { membuat saya jadi } \\
\text { sangat berkendala saat } \\
\text { harus mempersiapkan } \\
\text { ujian. }\end{array}$ & $\mathrm{A}_{3}=$ & $\begin{array}{l}\text { Saya juga mengalami } \\
\text { kebingungan dalam } \\
\text { memahami matematika, } \\
\text { bahkan hampir semua mata } \\
\text { pelajaran bu. Dan iru } \\
\text { membuat saya menjadi } \\
\text { tidak percaya diri dengan } \\
\text { teman-teman yang lain }\end{array}$ \\
\hline $\mathrm{Q}=$ & $\begin{array}{l}\text { Apakah menurutmu, } \\
\text { kemampuanmu dalam } \\
\text { matematika yang kamu } \\
\text { miliki mempengaruhi } \\
\text { kecemasan yang kamu } \\
\text { rasakan? }\end{array}$ & $\mathrm{Q}=$ & $\begin{array}{l}\text { Apakah menurutmu, } \\
\text { kemampuanmu dalam } \\
\text { matematika yang kamu } \\
\text { miliki mempengaruhi } \\
\text { kecemasan yang kamu } \\
\text { rasakan? }\end{array}$ & $\mathrm{Q}=$ & $\begin{array}{l}\text { Apakah menurutmu, } \\
\text { kemampuanmu dalam } \\
\text { matematika yang kamu } \\
\text { miliki mempengaruhi } \\
\text { kecemasan yang kamu } \\
\text { rasakan? }\end{array}$ \\
\hline $\mathrm{A}_{1}=$ & $\begin{array}{l}\text { Terkadang bu, } \\
\text { sebenarnya lebih } \\
\text { kearah terjadi multi- } \\
\text { persepsi dalam } \\
\text { memahami simbol } \\
\text { dalam materi } \\
\text { matematika }\end{array}$ & $\mathrm{A}_{2}=$ & $\begin{array}{l}\text { Sangat bu. Untuk saya } \\
\text { yang memiliki } \\
\text { kemampuan matematika } \\
\text { standar saya mengalami } \\
\text { kendala dan terkadang } \\
\text { merasa cemas. }\end{array}$ & $\mathrm{A}_{2}=$ & $\begin{array}{l}\text { Sangat bu. Selama } \\
\text { pembelajaran dalam } \\
\text { jaringan ini, jangankan } \\
\text { memahami materi. Saat } \\
\text { melihat materi yang di } \\
\text { share guru saja, saya sudah } \\
\text { sangat merasa tertekan. }\end{array}$ \\
\hline $\mathrm{Q}=$ & $\begin{array}{l}\text { Apakah kamu } \\
\text { menganggap bahwa } \\
\text { pembelajaran } \\
\text { matematika dalam } \\
\text { jaringan merupakan } \\
\text { pembelajaran yang } \\
\text { membosankan? }\end{array}$ & $\mathrm{Q}=$ & $\begin{array}{l}\text { Apakah kamu } \\
\text { menganggap bahwa } \\
\text { pembelajaran } \\
\text { matematika dalam } \\
\text { jaringan merupakan } \\
\text { pembelajaran yang } \\
\text { membosankan? }\end{array}$ & $\mathrm{Q}=$ & $\begin{array}{l}\text { Apakah kamu menganggap } \\
\text { bahwa pembelajaran } \\
\text { matematika dalam jaringan } \\
\text { merupakan pembelajaran } \\
\text { yang membosankan? }\end{array}$ \\
\hline $\mathrm{A}_{1}=$ & $\begin{array}{l}\text { Jika dibandingkan } \\
\text { dengan pembelajaran } \\
\text { tatap muka, saya juga } \\
\text { merasakan lebih bosan } \\
\text { sih bu. Meskipun pada } \\
\text { dasarnya saya merasa } \\
\text { senang dengan } \\
\text { matematika. }\end{array}$ & $\mathrm{A}_{2}=$ & $\begin{array}{l}\text { Terkadang sih bu, } \\
\text { pembelajaran } \\
\text { matematika ini memang } \\
\text { membuat saya bosan. } \\
\text { Tapi untuk memahami } \\
\text { materi dasar saya masih } \\
\text { merasa aman. }\end{array}$ & $\mathrm{A}_{3}=$ & $\begin{array}{l}\text { Sangat bu. Karena saya } \\
\text { sering merasa percuma join } \\
\text { room zoom karena saya } \\
\text { tetap merasa sulit paham } \\
\text { dan tetap berkendala. }\end{array}$ \\
\hline $\mathrm{Q}=$ & $\begin{array}{l}\text { Apakah kamu selalu } \\
\text { merasa cemas dalam } \\
\text { menunggu hasil ujian } \\
\text { matematika mu selama } \\
\text { proses pembelajaran } \\
\text { dalam jaringan ini? }\end{array}$ & $\mathrm{Q}=$ & $\begin{array}{l}\text { Apakah kamu selalu } \\
\text { merasa cemas dalam } \\
\text { menunggu hasil ujian } \\
\text { matematika mu selama } \\
\text { proses pembelajaran } \\
\text { dalam jaringan ini? }\end{array}$ & $\mathrm{Q}=$ & $\begin{array}{l}\text { Apakah kamu selalu } \\
\text { merasa cemas dalam } \\
\text { menunggu hasil ujian } \\
\text { matematika mu selama } \\
\text { proses pembelajaran dalam } \\
\text { jaringan ini? }\end{array}$ \\
\hline $\mathrm{A}_{1}=$ & $\begin{array}{l}\text { Saat menunggu hasil } \\
\text { ujian saya memang } \\
\text { terkadang merasakan } \\
\text { cemas sih bu, karena } \\
\text { beberapa bagian } \\
\text { memang kurang saya } \\
\text { kuasai. Tapi untuk } \\
\text { hasil sejauh ini masih } \\
\text { di atas KKM. }\end{array}$ & $\mathrm{A}_{2}=$ & $\begin{array}{l}\text { Tidak untuk semua } \\
\text { materi sih bu, hanya saja } \\
\text { untuk materi yang } \\
\text { benar-benar baru saya } \\
\text { dapatkan, saya lumayan } \\
\text { mengalami kecemasan } \\
\text { dalam menunggu hasil } \\
\text { ujian. }\end{array}$ & $\mathrm{A}_{3}=$ & $\begin{array}{l}\text { Lumayan bu, karena saya } \\
\text { sadar saya tidak } \\
\text { memahami materi dan } \\
\text { tetap membuat saya cemas } \\
\text { lebih kepada respon orang } \\
\text { tua saat mengetahui nilai } \\
\text { saya bu. Sejak awal saya } \\
\text { selalu mendapat nilai di } \\
\text { bawah KKM bu. }\end{array}$ \\
\hline
\end{tabular}




\begin{tabular}{|c|c|c|c|c|c|}
\hline $\mathrm{Q}=$ & $\begin{array}{l}\text { Apakah kamu merasa } \\
\text { lebih merasakan } \\
\text { ketegangan saat harus } \\
\text { mengikuti } \\
\text { pembelajaran } \\
\text { matematika dalam } \\
\text { jaringan? }\end{array}$ & $\mathrm{Q}=$ & $\begin{array}{l}\text { Apakah kamu merasa } \\
\text { lebih merasakan } \\
\text { ketegangan saat harus } \\
\text { mengikuti pembelajaran } \\
\text { matematika dalam } \\
\text { jaringan? }\end{array}$ & $\mathrm{Q}=$ & $\begin{array}{l}\text { Apakah kamu merasa lebih } \\
\text { merasakan ketegangan saat } \\
\text { harus mengikuti } \\
\text { pembelajaran matematika } \\
\text { dalam jaringan? }\end{array}$ \\
\hline $\mathrm{A}_{1}=$ & $\begin{array}{l}\text { Malah saya lebih } \\
\text { merasa situasi yang } \\
\text { fleksibel bu, karena } \\
\text { saya bisa belajar di } \\
\text { kamar/ di tempat lain } \\
\text { yang membuat saya } \\
\text { lebih nyaman. }\end{array}$ & $\mathrm{A}_{2}=$ & $\begin{array}{l}\text { Untuk ketegangan yang } \\
\text { sampai cemas sih tidak } \\
\text { bu, karena sisi lain saya } \\
\text { juga merasa nyaman } \\
\text { dengan situasi } \\
\text { pembelajaran dalam } \\
\text { jaringan ini. }\end{array}$ & $\mathrm{A}_{3}=$ & $\begin{array}{l}\text { Saya merasa tegang saat } \\
\text { tiba-tiba ditunjuk guru } \\
\text { untuk menjawab } \\
\text { pertanyaan saat } \\
\text { pembelajaran. Jadi } \\
\text { terkadang saya lebih } \\
\text { memilih untuk tidak join } \\
\text { bu. }\end{array}$ \\
\hline $\mathrm{Q}=$ & $\begin{array}{l}\text { Apakah kamu merasa } \\
\text { lebih tertekan saat } \\
\text { harus mengikuti } \\
\text { pembelajaran } \\
\text { matematika dalam } \\
\text { jaringan? }\end{array}$ & $\mathrm{Q}=$ & $\begin{array}{l}\text { Apakah kamu merasa } \\
\text { lebih tertekan saat harus } \\
\text { mengikuti pembelajaran } \\
\text { matematika dalam } \\
\text { jaringan? }\end{array}$ & $\mathrm{Q}=$ & $\begin{array}{l}\text { Apakah kamu merasa lebih } \\
\text { tertekan saat harus } \\
\text { mengikuti pembelajaran } \\
\text { matematika dalam } \\
\text { jaringan? }\end{array}$ \\
\hline $\mathrm{A}_{1}=$ & $\begin{array}{l}\text { Tidak sampai tertekan } \\
\text { sih bu, hanya saja } \\
\text { terkadang saya merasa } \\
\text { kesulitan dalam } \\
\text { memahami materi yang } \\
\text { membuat sedikit cemas } \\
\text { dan saya kurangi } \\
\text { dengan membuat } \\
\text { catatan menarik untuk } \\
\text { saya pelajari. }\end{array}$ & $\mathrm{A}_{2}=$ & $\begin{array}{l}\text { Sebenarnya lebih karena } \\
\text { tanggungan tugas yang } \\
\text { lebih banyak membuat } \\
\text { saya sering } \\
\text { mengumpulkan tugas } \\
\text { terlambat. Untuk sisanya } \\
\text { saya merasa aman sih } \\
\text { bu. }\end{array}$ & $\mathrm{A}_{3}=$ & $\begin{array}{l}\text { Saya merasa sangat } \\
\text { tertekan bu, bahkan dengan } \\
\text { kondisi rumah saya saat ini } \\
\text { membuat saya tidak bisa } \\
\text { mengikuti pembelajaran } \\
\text { seluruh mata pelajaran dan } \\
\text { membuat saya sangat } \\
\text { tertinggal. }\end{array}$ \\
\hline
\end{tabular}

\section{Pembahasan}

Berdasarkan seluruh hasil penelitian, salah satu hal terpenting yang perlu dibahas ialah megenai tingkatan kecemasan yang terjadi pada siswa tingkat menengah dalam menjalani pembelajaran dalam jaringan. Gambar 1 pada bagian hasil penelitian merupakan person map yang memberikan gambaran mengenai tingkatan kecemasan yang dialami oleh responden dalam menjalani pembelajaran dalam jaringan. Gambar 1 menyajikan data yang berasal dari 225 responden dan dianalisa menggunakan aplikasi Winsteps. Berdasarkan gambar 1 dapat terlihat bahwa kategori kecemasan dibagi menjadi tiga kategori kecemasan (kecemasan rendah, sedang, dan tinggi). Selaras dengan penelitian yang dilakukan Diana et al. (2020), hasil kecemasan dikategorikan menjadi tiga tingkatan (kecemasan rendah, sedang, dan tinggi).

Kecemasan yang terjadi cenderung masih tinggi dalam merespon pembelajaran dalam jaringan. Persentase dari setiap kelompok kecemasan matematika siswa dalam menjalani pembelajaran dalam jaringan dapat dilihat pada tabel 5. Selaras dengan penelitian yang 
dilakukan oleh oktawirawan yang menyatakan bahwa pelaksanaan pembelajaraan di rumah membuat sebagian anak merasa tertekan dan cemas (Oktawirawan, 2020). Begitupun dengan penelitian oleh Abdous (2019) menyatakan bahwa timbul kecemasan bagi siswa saat harus menghadapi perubahan pembelajaran tatap muka menjadi pembelajaran dalam jaringan.

Pembahasan selanjutnya mengenai respon pembelajaran yang memicu timbulnya kecemasan matematika selama pembelajaran matematika secara daring. Berdasarkan nilai probabilitas pada tabel 4 , seluruh item pernyataan pada kuisioner bernilai positif menyatakan bahwa responden menyetujui item-item pernyataan tersebut sebagai pemicu kecemasan. Berdasarkan kuisioner, pemicu kecemasan yang didapatkanberdasarkan survei ialah kebingungan dalam memahami materi, kesulitan dalam menentukan proses pembelajaran secara daring, kemampuan memecahkan masalah matematika, mendapatkan nilai yang rendah, anggapan bahwa matematika pelajaran membosankan, rasa tegang selama pembelajaran daring, perasaan tertekan dalam menjalani pembelajaran daring. Seluruh pemicu tersebut juga sejalan dengan kondisi psikologis siswa dalam menjalani pembelajaran matematika pada masa pandemi covid-19 yang menyatakan bahwa emosi, keyakinan, dan minat merupakan salah satu pemicu kecemasan yang hadir saat menjalani pembelajaran matematika secara dalam jaringan (Wulan et al., 2021).

Sedangkan, hal-hal yang masih menjadi perbedaan/bias dalam memicu hadirnya kecemasan matematika, dapat dilihat dari nilai probabilitas dibawah 0,05 pada tabel 5. Sehingga pada tabel 6 diperlihatkan hasil terperinci mengenai item yang masih terdapat perbedaan/bias membahas mengenai perasaan gugup selama pembelajaran daring, perasaan kesulitan selama pembelajaran daring, dan kemampuan dalam mengerjakan matematika. Pembahasan pertama ditinjau berdasarkan perasaan gugup selama mengikuti pembelajaran. Tabel 6 menyajikan data bahwa seluruh sebaran demografis mengalami bias terhadap item no.1 kecuali pada gender. Dalam tabel diperlihatkan bahwa sebaran yang tidak merasakan bahwa rasa gugup sebagai pemicu kecemasan pada pembelajaran daring terdapat pada siswa kelas $7(-0,3375)$, siswa 9 (0,0056), 11 (-0,3173), dan 12 (-0,5407). Jenjang pendidikan SMK (-0,8157) dan jurusan kejuruan $(-0,8157)$ juga menunjukkan hasil yang menyatakan bahwa perasaan gugup bukan sebagi pemicu kecemasan. Sedangkan berdasarkan domisili, Sumatera $(-0,9658)$ dan Kalimantan $(-19,874)$ juga tidak menjadikan perasaan gugup sebagai pemicu kecemasan. Dengan itu perasaan gugup dapat dijadikan penelitian yang lebih mendalam mengenai keberadaannya sebagai pemicu kecemasan. 
Selanjutnya perbedaan/bias terdapat pada item no.10 mengenai perasaan sulit selama menjalani pembelajaran matematika dalam jaringan. Berdasarkan sebaran demografi hanya gender baik laki-laki $(-0,5412)$ ataupun perempuan $(-11,898)$ tidak meyakini bahwa kesulitan sebagai pemicu hadirnya kecemasan. Berbeda dengan penelitian sebelumnya, membahas bahwa kecemasan berpengaruh pada kesulitan (Utami \& Warmi, 2019). Sedangkan dalam penelitian lain didapatkan bahwa berdasarkan gender perasaan sulit dalam pembelajaran membuat siswa tingkat menengah mendapatkan nilai jelek dan merasa malu dengan teman yang lainnya merupakan pemicu hadirnya kecamasan (Nofrialdi et al., 2018). Terakhir perbedaan/bias terdapat pada item no.16 mengenai kemampuan siswa tingkat menengah dalam mengerjakan matematika. Berdasarkan sebaran demografi, perbedaan/bias terdapat pada jenjang pendidikan jurusan pendidikan, dan domisili. Siswa SMK dan jurusan kejuruan menganggap kemampuan mengerjakan matematika bukanlah pemicu hadirnya kecemasan. Sedangkan berdasarkan domisili, hanya siswa yang berasal dari Kalimantan yang tidak merasa bahwa kemampuan mengerjakan matematika sebagai pemicu hadirnya kecemasan.

Bagian studi kualitatif dalam penelitian ini dapat memperkuat hasil penelitian secara kuantitatif. Siswa dengan inisial $A_{1}$ mewakili siswa dari tingkat kecemasan rendah. Siswa $A_{1}$ mengatakan bahwa dalam persiapan siswa merasa tidak ada hambatan berarti yang memicu hadirnya kecemasan karena siswa $\mathrm{A}_{1}$ termasuk siswa mempunyai fasilitas wifi dirumah dengan kualitas yang baik. Pada proses pembelajaran berlangsung, siswa $\mathrm{A}_{1}$ juga merasakan masih mampu mengatasi kesulitan-kesulitan pemicu kecemasan selama pembelajaran. Hanya saja kondisi pembelajaran secara dalam jaringan seringkali membuat terjadinya mis-persepsi mengenai pemahaman positif-negatif, dan beberapa pemahaman lainnya. Dalam proses pembelajaran siswa $A_{1}$ juga sering kurang memahami pembelajaran yang diberikan oleh guru, hanya saja siswa $A_{1}$ sering mencari materi tambahan di google ataupun youtube supaya bisa menjawab soal yang ditugaskan oleh guru. Pada bagian hasil pembelajaran siswa $\mathrm{A}_{1}$ merasa kondisi pembelajaran dalam jaringan membuat nilai hasil ujian masih diatas KKM, hanya saja baik pada ulangan harian ataupun penilaian tengah semester, dan akhir semester menjadi tidak stabil karena terdapat beberapa materi yang belum dipahami dengan maksimal. Menurut siswa $\mathrm{A}_{1}$, perasaan cemas terkadang hadir dalam menduga hasil ulangan, karena merasa pembelajaran dalam jaringan berbeda dengan pembelajaran pada umumnya. Sedangkan berdasarkan lingkungan sekolah, didapatkan informasi bahwa siswa $\mathrm{A}_{1}$ merupakan siswa yang sangat kreatif dalam membuat catatan, dapat mengikuti pembelajaran dengan baik, dan mendapatkan hasil yang baik dalam mata pelajaran matematika. 
Siswa $A_{2}$ yang mewakili siswa dengan tingkat kecemasan sedang juga merasa terdapat beberapa kecemasan selama mempersiapkan pembelajaran secara dalam jaringan. Siswa $\mathrm{A}_{2}$ diambil dari sampel yang memiliki akses kurang baik mengenai kebutuhan jaringan. Siswa $\mathrm{A}_{2}$ merasa kecemasan akan bertambah saat kondisi sinyal sedang tidak stabil dan membuat mereka merasa cemas dan khawatir tertinggal pelajaran dan tidak mempu memahami pembelajaran dengan baik. Pada proses pembelajaran berlangsung siswa $A_{2}$ merasa pembelajaran dalam jaringan sering membuat mereka cemas dan merasa tidak percaya diri untuk berperan aktif dalam menanggapi guru selama pembelajaran berlangsung mealui room meeting dalam jaringan. Sedangkan pada hasil pembelajaran yang didapatkan, siswa $\mathrm{A}_{2}$ merasa ia sering mengalami nilai yang kurang maksimal karena keterlambatan pengumpulan tugas dan merasa dengan pembelajaran dalam jaringan ini, mereka tak terlalu memikirkan besaran nilai, karena merasa enjoy saat pembelajaran dan dapat memahami materi saja mereka sudah senang.

Terakhir hasil wawancara dengan siswa $\mathrm{A}_{3}$ sebagai perwakilan siswa dengan tingkat kecemasan tinggi. Melalui gambar dari person map terlihat bahwa terdapat hal yang menarik pada responden ini. Hal tersebut terjadi karena respon siswa $\mathrm{A}_{3}$ dalam menjawab pernyataan cenderung menggambarkan kecemasan yang cukup tinggi dan menempatkan ia pada hasil terbawah dari tabel person map. Setelah dilakukan wawancara terstruktur terdapat informasi bahwa siswa $A_{3}$ memang mengalami kecemasan matematika yang sangat tinggi. Dalam menyiapkan pembelajaran daring, Siswa $\mathrm{A}_{3}$ mengalami kendala saat mempersiapkan pembelajaran. Siswa $A_{3}$ merasa tidak mampu mengikuti keseluruhan pembelajaran yang dilakukan dalam jaringan. Siswa $\mathrm{A}_{3}$ selalu merasa cemas dan merasa tak mampu mengikuti serangkaian pembelajaran. Siswa $\mathrm{A}_{3}$ juga merasa lebih cemas saat harus menghadapi ujian dan menunggu hasil ulangan. Melalui wawancara terstruktur siswa $\mathrm{A}_{3}$ menjelaskan seluruh hal yang terjadi dan ternyata Siswa $\mathrm{A}_{3}$ mengalami faktor eksternal yang memicu ia mengalami kecemasan tersebut. Kondisi pandemic saat ini berpengaruh pada kondisi keluarga siswa $\mathrm{A}_{3}$ dan menorehkan dampak yang cukup besar dengan psikisnya dalam menimbulkan kecemasan matematika yang cukup tinggi.

\section{Simpulan}

Kecemasan yang terjadi pada pembelajaran matematika dalam jaringan cenderung masih tinggi dan dapat dikategorikan menjadi tiga kategori. Kategori kecemasan matematika tersebut ialah kecemasan ringan 8,89\%, kecemasan sedang 73,78\%, dan kecemasan tinggi sebesar 17,33 \%. Berdasarkan penelitian didapatkan bahwa pemicu hadirnya kecemasan dalam 
pembelajaran matematika dalam jaringan ialah kebingungan dalam memahami materi, kesulitan dalam menentukan proses pembelajaran secara daring, kemampuan memecahkan masalah matematika, mendapatkan nilai yang rendah, anggapan bahwa matematika pelajaran membosankan, rasa tegang selama pembelajaran daring, dan perasaan tertekan dalam menjalani pembelajaran daring. Hasil ini dapat dijadikan referensi khususnya bagi tenaga pengajar dalam menganalisis kondsi siswa sebelum memilih pembelajaran dan pendekatan yang cocok untuk diterapkan dalam pembelajaran dalam jaringan yang akan mereka lakukan. Sedangkan pemicu yang masih menjadi perbedaan/bias terdapat pada perasaan gugup dalam menjalani pembelajaran, perasaan sulit selama pembelajaran, dan kemampuan dalam mengerjakan matematika. Hasil penelitian ini juga dapat dijadikan sebagai referensi untuk dilakukan penelitian lebih lanjut mengenai pemicu yang masih terdapat perbedaan/bias.

\section{Referensi}

Abdous, M. (2019). Influence of satisfaction and preparedness on online students' feelings of anxiety. Internet and Higher Education, 41(January), 34-44. https://doi.org/10.1016/j.iheduc.2019.01.001.

Apsari, R. A., Sripatmi, S., Sariyasa, S., Maulyda, M. A., \& Salsabila, N. H. (2020). Pembelajaran matematika dengan media obrolan kelompok multi-arah sebagai alternatif kelas jarak jauh. Jurnal Elemen, 6(2), 318-332. https://doi.org/10.29408/jel.v6i2.2179.

Ardi, Z., Rangka, I. B., Ifdil, I., Suranata, K., Azhar, Z., Daharnis, D., Afdal, A., \& Alizamar, A. (2019). Exploring the elementary students learning difficulties risks on mathematics based on students mathematic anxiety, mathematics self-efficacy and value beliefs using rasch measurement. Journal of Physics: Conference Series, 1157(3), 032095. https://doi.org/10.1088/1742-6596/1157/3/032095.

Catherine, R. N. (2020). Siswa belajar dari rumah, KPAI: anak-anak stres dikasih banyak tugas. Diambil dari https://news.detik.com/berita/d-4944071/siswa-belajar-dari-rumahkpai-anak-anak-stres-dikasih-banyak-tugas.

Diana, P., Marethi, I., \& Pamungkas, A. S. (2020). Kemampuan pemahaman konsep matematis siswa: Ditinjau dari kategori kecemasan matematik. SJME (Supremum Journal of Mathematics Education), 4(1), 24. https://doi.org/10.35706/sjme.v4i1.2033.

Disai, W. I., Dariyo, A., \& Basaria, D. (2017). Hubungan antara kecemasan matematika dan self-efficacy dengan hasil belajar matematika siswa sma x kota palangka raya. Muara Ilmu Sosial, Humaniora, dan Seni, 1(2), 556-568. https://doi.org/10.24912/jmishumsen.v1i2.799.

Handayani, S. D. (2019). Pengaruh kecemasan matematika terhadap pemahaman konsep matematika. SAP (Susunan Artikel Pendidikan), 4(1). https://doi.org/10.30998/sap.v4i1.3708.

Hastini, L. Y., Fahmi, R., \& Lukito, H. (2020). Apakah pembelajaran menggunakan teknologi dapat meningkatkan literasi manusia pada generasi $\mathrm{Z}$ di Indonesia? Jurnal Manajemen Informatika (JAMIKA), 10(1), 12-28. https://doi.org/10.34010/jamika.v10i1.2678.

Ikhsan, M. (2019). Pengaruh kecemasan matematis terhadap hasil belajar matematika. De Fermat: Jurnal Pendidikan Matematika, 2(1), 1-6. https://doi.org/10.36277/defermat.v2i1.28.

Janah, S. R., Suyitno, H., \& Rosyida, I. (2019). Pentingnya literasi matematika dan berpikir 
kritis matematis dalam menghadapi abad ke-21. PRISMA, Prosiding Seminar Nasional Matematika, 2, 905-910.

Jend, J., No, S., \& Cikokol, M. (2012). Sensitivity of differential item functioning (DIF) sensitivitas metode pendeteksian differential item functioning (DIF). Jurnal Evaluasi Pendidikan, 3(1), 82-94. https://doi.org/10.21009/JEP.031.07.

Jolejole-Caube, C., Dumlao, A. B., \& Abocejo, F. T. (2019). Anxiety towards mathematics and mathematics performance of grade 7 learners. European Journal of Education Studies, 6(1), 344-360.

Juliyanti, A., \& Pujiastuti, H. (2020). Pengaruh kecemasan matematis dan konsep diri terhadap hasil belajar matematika siswa. Prima: Jurnal Pendidikan Matematika, 4(2), 75. https://doi.org/10.31000/prima.v4i2.2591.

Kusmaryono, I., Nuhyal Ulia, dan, Kaligawe Raya, J. K., Kulon, T., \& Tengah, J. (2020). Interaksi gaya mengajar dan konten matematika sebagai faktor penentu kecemasan matematika. Mosharafa: Jurnal Pendidikan Matematika, 9(1), 143-154.

Kusumawardani, D. R., Wardono, \& Kartono. (2018). Pentingnya penalaran matematika dalam meningkatkan kemampuan literasi matematika. Prisma, 1(1), 588-595.

Kusumawati, R., \& Nayazik, A. (2017). Kecemasan matematika siswa SMP. Journal of Madives, 1(2), 92-99.

Morgan, H. (2020). Best practices for implementing remote learning during a pandemic. The Clearing House: A Journal of Educational Strategies, Issues and Ideas, 93(3), 135-141. https://doi.org/10.1080/00098655.2020.1751480.

Mulyana, A., Senajaya, A. J., Ismunandar, D., \& Kunci, K. (2021). Indikator-indikator kecemasan belajar matematika daring di era pandemik COVID-19 menurut perspektif siswa SMA kelas X. Penelitian Matematika dan Pendidikan Matematika, 4, 14-22. https://doi.org/10.30605/proximal.v4i1.501.

Nabilah, E., Azhar, E., Purwanto, S. E., \& Nabilah, E. (2021). Kecemasan siswa dalam menyelesaikan masalah modelling matematika pada praktek kelas virtual. Internatioinal Journal of Progressive Mathematics Education, 1(1), 41-60.

Namkung, J. M., Peng, P., \& Lin, X. (2019). The relation between mathematics anxiety and mathematics performance among school-aged students: A meta-analysis. Review of Educational Research, 89(3), . https://doi.org/10.3102/0034654319843494.

Ningsih, S. K., Narahara, S., \& Mulyono, H. (2018). An exploration of factors contributing to students' unwillingness to communicate in a foreign language across Indonesian secondary schools. International Journal of Instruction, 11(4), 811-824. https://doi.org/10.12973/iji.2018.11451a.

Nofrialdi, I., Maison, M., \& Muslim, M. (2018). Tingkat kecemasan matematika siswa SMA Negeri 2 Kerinci kelas X MIA sebelum menghadapi tes matematika berdasarkan gender dan hubungannya dengan hasil belajar. Edumatika: Jurnal Riset Pendidikan Matematika, 1(2), 11. https://doi.org/10.32939/ejrpm.v1i2.248.

Oktawirawan, D. H. (2020). Faktor pemicu kecemasan siswa dalam melakukan pembelajaran daring di masa pandemi COVID-19. Jurnal Ilmiah Universitas Batanghari Jambi, 20(2), 541. https://doi.org/10.33087/jiubj.v20i2.932.

Purwanto, A., Pramono, R., Asbari, M., Santoso, P. B., Wijayanti, L. M., Choi, C. H., \& Putri, R. S. (2020). Studi eksploratif dampak pandemi COVID-19 terhadap proses pembelajaran online di sekolah dasar. EduPsyCouns: Journal of Education, Psychology and Counseling, 2(1), 1-12.

Puspaningtyas, N. D. (2019). Berpikir lateral siswa SD dalam pembelajaran matematika. Mathema Journal, 1(1), 24-30.

Putria, H., Maula, L. H., \& Uswatun, D. A. (2020). Analisis proses pembelajaran dalam jaringan (daring) masa pandemi COVID-19 pada guru sekolah dasar. Jurnal Basicedu, 4(4), 861- 
870. https://doi.org/10.31004/basicedu.v4i4.460.

Recber, S., Isiksal, M., \& Koç, Y. (2018). Investigando la autoeficacia, la ansiedad, las actitudes y los logros de las matemáticas con respecto al género y el tipo de escuela. Anales de Psicologia, 34(1), 41-51. https://doi.org/10.6018/analesps.34.1.229571.

Rizki, F., Rafianti, I., \& Marethi, I. (2019). Pengaruh kecemasan matematika terhadap kemampuan pemecahan masalah siswa di SMA. GAUSS: Jurnal Pendidikan Matematika, 2(2), 11. https://doi.org/10.30656/gauss.v2i2.1750.

Santri, F. S. (2017). Ada apa dengan kecemasan matematika? Journal of Medives, 1(1), 59-65.

Setiawan, M. A., Susongko, P., \& Hayati, M. N. (2016). Pendeteksian DIF pada perangkat tes objektif penilaian akhir semester IPA dengan mengunakan permodelan Rasch. Pancasakti Science Education Journal, 7(1), 1-8.

Shukla, T., Dosaya, D., Nirban, V. S., \& Vavilala, M. P. (2020). Factors extraction of effective teaching-learning in online and conventional classrooms. International Journal of Information and Education Technology, 10(6), 422-427. https://doi.org/10.18178/ijiet.2020.10.6.1401.

Siregar \& Restati. (2017). Persepsi siswa pada pelajaran matematika: Studi pendahuluan pada siswa yang menyenangi game. Prosiding Temu Ilmiah X Ikatan Psikologi Perkembangan Indonesia, 224-232.

Sudihartinih, E., \& Wahyudin. (2019). Analysis of students' self efficacy reviewed by geometric thinking levels and gender using rasch model. Journal of Engineering Science and Technology, 14(1), 509-519.

Sumintono, B., \& Widhiarso, W. (2014). Aplikasi model Rasch untuk penelitian ilmu-ilmu sosial (b. Trim (ed.); edisi revi). Indonesia: Trim Komunikata Publishing House.

Sumintono, B., \& Widyiarso, W. (2015). Aplikasi pemodelan Rasch pada assessment pendidikan. Indonesia: Trim Komunikata Publishing House.

Utami, A. H., \& Warmi, A. (2019). Analisis kesulitan belajar ditinjau dari rasa kecemasan matematika. Sesiomadika Journal, 617-622.

Utami, Y. P., Alan, D., \& Cahyono, D. (2020). Study at home: Analisis kesulitan belajar matematika pada proses pembelajaran daring. Jurnal Ilmiah Matematika Realistik (JIMR), 1(1), 20-26. https://doi.org/10.33365/ji-mr.v1i1.252.

Wijaya, R., Fahinu, F., \& Ruslan, R. (2019). Pengaruh kecemasan matematika dan gender terhadap kemampuan penalaran adaptif matematika siswa SMP Negeri 2 Kendari. Jurnal Pendidikan Matematika, 9(2), 173. https://doi.org/10.36709/jpm.v9i2.5867.

Willse, J. T. (2017). Polytomous rasch models in counseling assessment. Measurement and Evaluation in Counseling and Development, 50(4), 248-255. https://doi.org/10.1080/07481756.2017.1362656.

Wulan, D. R., Rosita, C. D., \& Nopriana, T. (2021). Bagaimana psikologi siswa SMP dalam pembelajaran matematika online pada masa pandemi COVID-19. JNPM (Jurnal Nasional Pendidikan Matematika), 5(1), 51-65. https://doi.org/10.33603/jnpm.v5i1.4392.

Zakariya, Y. F. (2018). Development of mathematics anxiety scale: Factor analysis as a determinant of subcategories. Journal of Pedagogical Research, 2(2), 135-144. 